\title{
The influence of context in the implementation of a smart city project: the case of Cidade Inteligente Búzios
}

\author{
Mariana Brandão1 \\ Luiz Antonio Joia ${ }^{2}$ \\ 1 Universidade do Grande Rio (Unigranrio) / Programa de Pós-Graduação em Administração, Rio de Janeiro / RJ — Brazil \\ ${ }^{2}$ Fundação Getulio Vargas / Escola Brasileira de Administração Pública e de Empresas, Rio de Janeiro / RJ — Brazil
}

The growth of urban population is widely acknowledged to be a central trend that poses challenges for the administration of cities worldwide. In this context, several advances in information and communication technologies (ICTs) have been developed to gradually transform urban centers into smart cities. In this article, we seek to contribute to filling a knowledge gap in the literature on smart city — namely the lack of empirical data in works on this subject - by investigating a project aimed at turning the municipality of Búzios in Brazil into a smart city, named Cidade Inteligente Búzios (CIB). Our objective is, thus, to describe and understand the controversial influence of the context in the implementation of the project, which was considered a success for some actors and irrelevant for others, a situation that defies the very concept of success in the implementation of smart cities.

Keywords: smart city; actor-network theory; cidade inteligente Búzios; project success; urban development.

\section{A influência do contexto na implantação de um projeto de cidade inteligente: 0 caso Cidade Inteligente Búzios}

O crescimento da população urbana é reconhecido como uma tendência que desafia a administração das cidades ao redor do mundo. Nesse contexto, vários avanços nas tecnologias de informação e comunicação (TICs) vêm sendo desenvolvidos para transformar gradualmente os centros urbanos em cidades inteligentes. Por meio deste artigo, procuramos contribuir para preencher uma lacuna de conhecimento na literatura atual sobre cidades inteligentes - a falta de dados empíricos em trabalhos sobre esse assunto - investigando um projeto que visa transformar o município de Búzios no Brasil em uma smart city, denominado Cidade Inteligente Búzios (CIB). Assim, o objetivo deste artigo é descrever e entender a controversa influência do contexto na implantação do projeto, já que o empreendimento foi considerado um sucesso por alguns atores, e, ao mesmo tempo, irrelevante por outros, o que desafia o próprio conceito de sucesso na implantação de cidades digitais.

Palavras-chave: smart city; teoria ator-rede; cidade inteligente Búzios; sucesso em projeto; desenvolvimento urbano.

\section{La influencia del contexto en la implementación de un proyecto de ciudad inteligente: el caso de Cidade Inteligente Búzios}

El crecimiento de la población urbana es reconocido como una tendencia que desafía a la administración de las ciudades de todo el mundo. En este contexto, varios avances en las tecnologías de la información y la comunicación (TIC) se han desarrollado para transformar gradualmente centros urbanos en ciudades inteligentes. En este artículo, intentamos llenar a un vacío de conocimiento en la literatura actual sobre ciudades inteligentes, la ausencia de dados empíricos en trabajos sobre el tema, investigando el proyecto de transformación de la ciudad de Búzios en Brasil en una ciudad inteligente, denominado Cidade Inteligente Búzios (CIB). Así, tenemos el objetivo de plantear y entender la controvertida influencia del contexto en el desarrollo dese proyecto, puesto que el emprendimiento ha sido considerado un suceso por algunos actores, mientras como irrelevante por los otros, lo que desafía el propio concepto de suceso en la implantación de ciudades inteligentes.

Palabras clave: smart city; teoría actor-red; Cidade Inteligente Búzios; suceso en proyecto; desarrollo urbano. 


\section{INTRODUCTION}

In recent decades, the general trend in the world has been the increasing concentration of the population in urban areas of both developed and developing countries. In fact, from 2007 onwards, the global urban population have started to exceed the global rural population with an everincreasing growth of people living in cities worldwide (United Nations, 2015). In this way, the United Nations (2015) expects that by 2050 nearly 70 per cent of the total population will be living in urban areas. However, the rapid and unplanned urban growth poses significant threats to the sustainable development of cities and challenges their administrations to ensure their livable conditions (Chourabi et al., 2012). In this context, several advances in information and communication technologies (ICT) have been proposed in order to alleviate such strain and transform urban centers into smart cities (Sarkar, 2015).

Fundamentally, the term smart city has been differently defined in the extant literature (Ramaprasad et al., 2017). In a very simplistic way, it regards an "urban environment which, supported by pervasive ICT systems, is able to offer advanced and innovative services to citizens in order to improve the overall quality of their life" (Piro et al., 2014:169). Ideally, smart city initiatives will lead to more efficient and cost-effective solutions to urban problems, ranging from mobility, energy use, $\mathrm{CO} 2$ emissions and resource use efficiency (March and Ribera-Fumaz, 2016).

Despite the fact that the smart city idea has been most of the time uncritically celebrated by the academic, policymaking and think-tank literature (e.g., Caragliu et al., 2011; Sarkar, 2015), there is an emerging body of literature that criticizes the dominant triumphalist view associated with the smart city concept (e.g., Vanolo, 2013; Thrift, 2014). The latter set of literature argues that smart city is a somewhat nebulous idea that is being deployed more on an imaginary level, with grand visions of future urban utopias, rather than materially (March and Ribera-Fumaz, 2016). In addition, some scholars have observed that smart city discourses embrace the rhetoric of "practical" visions and plain "common sense" language in order to increase the smart city appeal to contemporary policy agendas across the global landscape (Gibbs et al., 2013).

Yet, that critical literature, vital in countering the apparently commonsensical vision of smart cities, has a few shortcomings that inhibit making sense of and refashioning the smart city agenda (Kitchin, 2015). For instance, the urbanization process in different places generates different challenges and potentials due to the pre-existing conditions (Fleury et al., 2008). However, given the absence of empirical case studies of specific smart city initiatives, the literature often presents canonical examples and one-size fits all narratives (Bulkeley et al., 2016). In this sense, Glasmeier and Christopherson (2015) support that the contribution of scholarly community in evolving discussions of the city of the future will rest on the ability to produce solid, detailed and effective empirical studies of the process of urban transformation.

Hence, we seek to answer the abovementioned call for solid empirical case studies of specific smart city initiatives by employing the Actor-Network Theory (ANT) to examine the smart city project named Cidade Inteligente Búzios (CIB). In particular, we aim to set forth and understand the challenging context influence in the implementation of the aforementioned project and, by consequence, probe why the smart city project analyzed was considered as a success for some actors, while as irrelevant for others, which defies the very concept of success in smart cities implementation. 
We structured this article as follows: in section 2, we present a review of the literature on smart city and ANT. Then, in section 3, we describe the research method. In section 4, we explain the context in which the CIB project was developed and, in section 5, we examine the implementation of such project from the ANT standpoint. Section 6, in turn, is dedicated to discussing the results accrued from the case study. Finally, in section 7 we present our concluding remarks.

\section{LITERATURE REVIEW}

\subsection{SMART CITY}

The rapid increase of urban population worldwide has raised a variety of technical, social, economic and organizational problems (i.e. waste management, scarcity of resources, traffic congestion, pollution, and increasing social inequality) that tend to jeopardize the economic and environmental sustainability of cities (Neirotti et al., 2014). In this context, the concept of smart city has emerged, in which new technology-based solutions as well as new approaches to urban planning and living intend to assure future feasibility and prosperity to metropolitan areas (Chourabi et al., 2012).

In the early 1990s, when the term "smart city" was first used, it was meant to highlight the importance of new ICT to overcome the challenges of cities within a global knowledge economy (Chourabi et al., 2012). More recently, the smart city concept was broadened as scholars acknowledged that factors such as human capital/education and environmental issues are also drivers of a city's improvement. As such, Neirotti and collaborators (2014) propose that a smart city comprises two domains, namely "hard" and "soft". While in the hard domain, ICT can play a decisive role in the improvement of the city systems (e.g. office and residential buildings, energy and water management, waste management, transport, mobility, and logistics), in the soft domain, ICT has a more limited role (e.g. education, culture, policy innovations, social inclusion, and government).

According to Nam and Pardo (2011), a smart city represents city innovation in management and policy as well as technology. As such, it regards a living laboratory for experiment, which necessarily entails unavoidable risks (generated by new, untested trials). Similarly, Tironi and Sánchez Criado (2015) argue that the principal development strategy of smart city projects consists of pilot studies, allowing large companies to test technological and service prototypes, carrying out different forms of "urban laboratories" to test and demonstrate the durability and "social" integration of their products and services.

Despite the heavy corporate investment in promoting the concept, smart city business models and applications usually reveal far more uncertainties than certainties, its technological devices being more speculative and exploratory than decisive or definitive in character (Tironi and Sánchez Criado, 2015). That is to say, the real benefits of smart city initiatives so far are inconclusive, as most of the cases have not yet achieved a well-defined level of solidification and stabilization as a closed socio-technical system (Thrift, 2014).

Interestingly, with the notable exception of some works (Greenfield, 2013; Klauser and Albrechtslund, 2014; Luque-Ayala and Marvin, 2015), the current understanding of smart city lacks a critical perspective compounded by an undue emphasis on technological solutions that disregard 
the political domain. Thus, for some authors smart city might be interpreted as yet another strand in the consolidation of dominant circuits of capital and a neoliberal governmentality (Vanolo, 2013) or as a new governmental form altogether (Gabrys, 2014).

For Luque-Ayala and Marvin (2015), research on smart city has not focused on the contradictions of the smart city concept, its differential expression across global North and South, and the potential this creates to develop more oppositional, contested forms of knowledge and subjectivity that emerge from these contexts.

In Brazil, we perceive that most of research on smart cities follows a twofold approach. One strand addresses the technological issues related to smart cities implementations (Borja and Gama, 2014) as well as proposes maturity models to assess such initiatives (Gama et al., 2012). On the other hand, the second strand describes and discusses the implementation of smart cities endeavors in Brazil (Weiss et al., 2015; Weiss et al., 2017). Yet, we notice that both approaches lack a critical view of smart cities, being very much focused on the technological issue of a smart city. There are yet few recent works that tackle this knowledge field in a critical (Weiss and Consoni, 2017) and more holistic perspective such as the role of smart cities in a new public administration and governance model (Madeira et al., 2017).

Therefore, in search of that critical perspective, it seems to be paramount to analyze the influence of the context in smart cities implementations in Brazil (Avgerou, 2001, 2008), being this what we intend to do addressing the CIB project in this work.

\subsection{ACTOR-NETWORK THEORY (ANT)}

As observed by Nam and Pardo (2011), a sociotechnical view is required to achieve a deep and thorough understanding of smart city projects. Accordingly, as ANT makes it possible to frame the analysis of the interplay between technology and society in the middle ground amid two conflicting approaches (technological determinism and social determinism), it is entirely suitable for sociotechnical research (Díaz Andrade and Urquhart, 2010).

Typically, ANT portrays society as a sociotechnical web (actor-network) where technical objects participate in constantly building heterogeneous networks that bring together actors (or actants) of all types (Murdoch, 1997). From ANT's perspective, human and non-human actors are considered without distinction (Américo and Takahashi, 2014), so that any person or device that is able to impose their language to others can be considered an actor in a network (Latour, 2005). Furthermore, the number of connections that an actant has with different actors and networks determine what the actant is and what he, she or it can do through a series of negotiations (Latour, 2005).

The concept of translation, widely used in ANT studies, "is the mechanism by which the social and natural worlds progressively take form" (Callon, 1986:206). That is, the success in implementing some project is achieved by the translation of the various actors involved in such project into a common goal, called obligatory passage point (OPP) (Fornazin and Joia, 2015). According to Callon (1986), the translation process comprises four moments - problematization, interessement, enrolment, and mobilization - as shown in figure 1 .

Establishing the network requires the four stages to be realized in full; otherwise, it never stabilizes (Díaz Andrade and Urquhart, 2010). The outcome of this process is a situation in which certain entities control others, who are persuaded to act in accordance with the requirements of the network. 


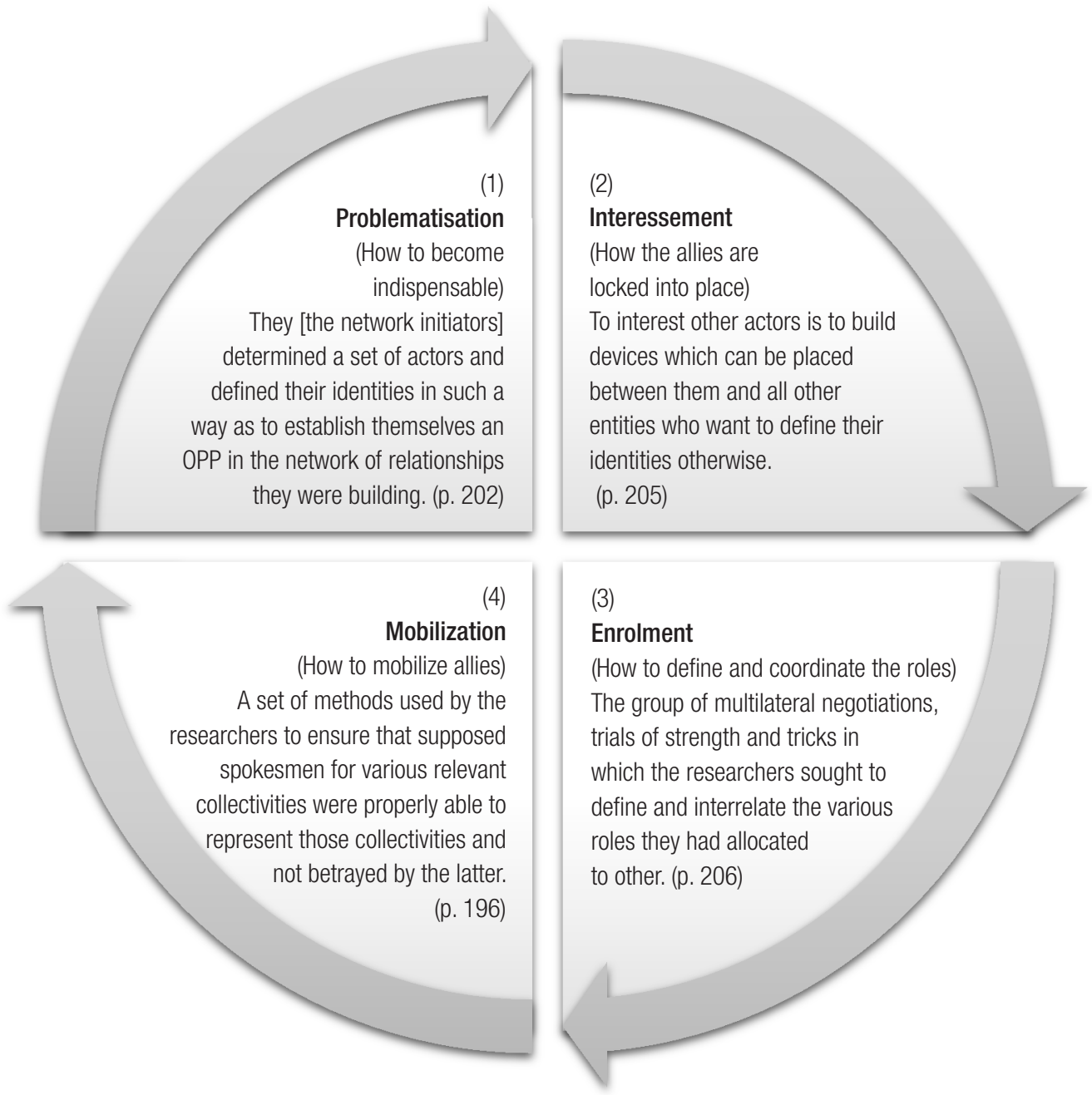

Source: Adapted from Callon (1986).

The ANT follows the critical-interpretive perspective (Walsham, 1997; Pozzebon, 2004; Mitev and Howcroft, 2011). While ANT has no explicit critical facet when used to rebuild a sociotechnical network and the actions of its components without refusing to take for granted a priori distinctions, it shed a critical light on what is assumed and mundane, as well as on the actual status-quo (Doolin and Lowe, 2002). Thus, controversies arise, for instance, from the differences between the sundry stakeholders' interests over the implementation of a technological project. That way, scientific works using ANT aims to depict a reality that may lead readers to a critical reflection (Klecun, 2004).

In this vein, in Brazil, Ramos (2009) analyzed the network of actors associated with the informatics national policy between 1960 and 2009. Besides, Andrade (2013) investigated how the electronic process system was spread among the justice courts. Moreover, extant theoretical models were also adjusted via empirical observations interpreted via the ANT approach (Teles and Joia, 2011; 
Cavalheiro and Joia, 2014). These works, with heavy empirical character, produced relevant and critical contribution for the understanding of the trajectory of technological projects in Brazil.

In our view, the main merit of ANT for this study is that, by tracking the history of the translation, it allows us to observe the actors' disparate goals, which eventually lead to the failure of establishing a network of actors as planned by the project sponsor. Since smart cities are living labs for experiment, their outcomes cannot be predicted in definite terms. Thus, by tracing the interactions between humans and non-humans via ANT, we are able to understand the role of context in the implementation of the $\mathrm{CIB}$ project and the negotiation process - characterized by simultaneous resistance and compromise - over the implementation of the same.

\section{RESEARCH METHOD}

Essentially, this research concerns a case study associated with the Actor-Network Theory. In short, a case study examines a phenomenon in its natural settings, employing multiples methods of data collection to gather information from one or more entities (Stake, 1995).

Stake (2006) identifies three types of case study, namely intrinsic, instrumental, and collective. The CIB case can be considered to be both intrinsic and instrumental. Stake (1995) uses the term intrinsic when researchers have a genuine interest in the case itself. Thus, the case under analysis is not chosen primarily because it represents other cases or unveils a particular trait or problem, but because we have interest on the case itself due to its particularity and ordinariness (Gregor, 2006). However, the CIB case can also be considered as being instrumental because an effort is made by us to reveal relevant and actionable knowledge that might be transferable to other similar contexts (Avgerou, 2008; Diniz et al., 2012).

Furthermore, we embraced in this article a qualitative perspective grounded on a critical interpretivist paradigm. Although critical interpretative case studies do not share positivist values, they are also subject to criteria to ensure their quality (Pozzebon, 2004). As such, we developed this study considering Pozzebon's (2004) four criteria list for conducting and evaluating a critical-interpretive research, namely authenticity, plausibility, criticality, and reflexivity (box 1).

BOX 1 INDICATORS OF CRITICAL-INTERPRETIVE RESEARCH QUALITY

DESCRIPTION
$\begin{aligned} & \text { CRITERION } \\ & \text { The researcher(s) must have contact with the field to interact with the participants and access the } \\ & \text { documents. }\end{aligned}$
$\begin{aligned} & \text { It refers to the capacity of the text to have meaning for the readers, that is, to have a good argument } \\ & \text { and structure for their comprehension, besides being relevant to them. }\end{aligned}$




DESCRIPTION
$\begin{aligned} & \text { CRITERION } \\ & \text { The text should encourage readers to question the prevailing and conventional views presented in a } \\ & \text { study, in other words to re-examine the premises that underpin the work. }\end{aligned}$
Triticality
$\begin{aligned} & \text { The author(s) must contribute to the study by describing his/her/their activities and visions about the } \\ & \text { research, revealing his/her/their role(s) in the research, as well as his/her/their personal idiosyncrasies } \\ & \text { and premises. }\end{aligned}$

Source: Based on Pozzebon (2004).

\subsection{DATA COLLECTION}

Latour (2005:68) defines the working of ANT as "follow the actors in their weaving through things they have added to social skills so as to render more durable the constantly shifting interactions."

Thus, we gathered an extensive empirical material over the implementation of the CIB project including semi-structured interviews, observations, internal company documentation (e.g. reports, meeting records, researches) and publicly available information about the project and its implementation. In fact, since the beginning of our research, the company (Ampla) was very open and receptive, providing us with information.

In total, 21 semi-structured interviews were conducted by us for this research, including political leaders, people directly involved in projects related to $\mathrm{CIB}$, civil society representatives, researchers, and tradespeople. In the text, we labeled the interviewees as Ii, where $\mathrm{i}=1$ to 21 and their quotations as $\mathrm{Qj}$, where $\mathrm{j}$ identifies the order of the quotation collected by us.

We chose the interviewees via snowball technique. We initially contacted the project manager of the smart city project as well as some local inhabitants. Then, they indicated other persons to be interviewed by us. The interviews were staged between December 2015 and March 2017, lasting from 40 to 90 minutes and being all recorded and transcribed verbatim by us.

As for a qualitative research, the data quality is more important them the number of interviews (McCracken, 1988), we stopped interviewing based on the saturation strategy, namely the new informants could not provide us with new data (Bauer and Aarts, 2002).

In box 2, we present the characteristics of the 21 interviews conducted.

\section{BOX 2 CHARACTERISTICS OF THE INTERVIEWS CONDUCTED}

\begin{tabular}{ll} 
Interviewees' Caption & \multicolumn{1}{c}{ Relation to the city/smart city project } \\
\hline 11 & Director of R\&D and Innovation sector of Ampla \\
\hline 12 & Director of Ampla's Socioeconomic Development and Sustainability sector \\
I3 & Cieds $^{1}$ 's person responsible by the CIB project
\end{tabular}




\begin{tabular}{|c|c|}
\hline Interviewees' Caption & Relation to the city/smart city project \\
\hline 14 & Lives in Búzios — director of the local Hotels and Inns Association (AHB) \\
\hline 15 & $\begin{array}{l}\text { Lives in Búzios - temporally hired by Ampla to work at the project monitoring and research center in } \\
\text { Búzios }\end{array}$ \\
\hline 16 & $\begin{array}{l}\text { Lives in Búzios - temporally hired by Ampla to work at the projects monitoring and research center in } \\
\text { Búzios }\end{array}$ \\
\hline 17 & Employee at the Búzios' secretariat of tourism \\
\hline 18 & $\begin{array}{l}\text { Director of Tecnoclad — a company that proposes and develops R\&D projects for electricity } \\
\text { distribution dealers }\end{array}$ \\
\hline 19 & $\begin{array}{l}\text { Researcher from Coppe/UFRJ — external institution that developed the distributed generation } \\
\text { research for the project }\end{array}$ \\
\hline 110 & Ampla's R\&D and Innovation sector staff \\
\hline 111 & Lives in Búzios — taxi driver \\
\hline 112 & Lives in Búzios — secretary of science and technology \\
\hline 113 & Lives in Búzios — secretary of tourism \\
\hline 114 & Lives in Búzios — condo gatekeeper \\
\hline 115 & Lives in Búzios — inn owner \\
\hline 116 & Lives in Búzios — inn owner \\
\hline 117 & Has a house in Búzios - does not live in the city \\
\hline 118 & Lives in Búzios — hotel front desk \\
\hline 119 & Amplas' employee responsible for the project's automation network \\
\hline 120 & PhD student at Fluminense Federal University (UFF) — researching about the project \\
\hline 121 & Lives in Búzios — works with construction \\
\hline
\end{tabular}

Source: Elaborated by the authors.

\subsection{DATA ANALYSIS}

Before starting to explain how we conducted the data analysis, we need to present ourselves to the readers in order to attend the reflexivity criterion for critical-interpretive research (box 1).

First, we know very much Armação dos Búzios (a.k.a Búzios) since it was an under-developed tourism destination. In other words, the context is not unknown for us, on the contrary. Besides, we have worked with ANT for a long time mainly associated with ICT4D (Information and Communication for Development) research. Thus, we developed a very critical view on mimicking, in developing countries, successful ICT initiatives undertaken in developed countries. In a nutshell, we very much believe that context matters in ICT endeavors, a belief that is also supported by Avgerou (2001, 2008). Besides, following Sen's ideas (Sen, 2001), we also challenge the concept of "development" and the role of ICT on this (Walsham, 2012). In sum, we believe that "development" is a social construct imposed 
by the Global North to the Global South, being ICT a critical enabler of such development. Based on that, and being smart city a technocentric concept developed by the Global North (Greenfield, 2013), we are aware of our possible and potential bias when interpreting the data collected and generating our findings. In order to counterbalance this, we have asked "techno-evangelists" colleagues to read and criticize our manuscript. Yet, we are conscious that our bias may linger on. With that in mind, we present below how we analyzed the data collected.

As mentioned earlier, we used ANT as the analytic device for examining the implementation of the smart city project. Therefore, we ascertained the four stages that comprises the translation process (figure 1) in order to identify mechanisms that established the socio-technical network of the various heterogeneous actors associated with the implementation of the CIB project. For doing that, we developed a coding scheme based on code families reflecting different aspects of the four stages of the translation process. That way, we managed to link the collected data, namely semi-structured interviews, our notes based on observations, internal company documentation (e.g. reports, meeting records, researches) and publicly available information about the project to the phases of the translation process in the ANT as depicted in figure 1.

The evaluation reliability and agreement should be part of the development of coding schemes for qualitative data in order to satisfy people that the data are sound (Hruschka et al., 2004). Therefore, we analyzed the discriminant capability of the coding scheme. This involves determining how well the excerpts chosen could readily and unambiguously be categorized into one of the ANT translation stages (Kurasaki, 2000). Then, we solved the unitization (Krippendorff, 1995) issue. This problem arises when portions of the excerpts require the subjective interpretation of the coder. This is a problem insofar as different coders may unitize the same text differently as they may disagree on which segments of text are associated with a particular stage of the ANT translation process (Kurasaki, 2000). Particularly in situations like ours, where we coded free responses to open-ended questions, identifying the appropriate unit of analysis can be difficult. Thus, we asked third-parties who are knowledgeable about ANT to reproduce what we have done. We have used the software Atlas.ti to help us on this endeavor (Friese, 2014).

Lastly, in order to guarantee the quality of this critical-interpretive research, we adopted several techniques as unveiled in box 3 .

BOX 3 DATA ANALYSIS TECHNIQUES ADOPTED

CRITERION
$\begin{aligned} & \text { AECHNIQUE ADOPTED } \\ & \text { An attempt was made by us to demonstrate the authenticity of this study using several sources of } \\ & \text { evidence collected during field research, namely: (a) interviews with actors identified as relevant to } \\ & \text { the CIB project; (b) access to documents such as interviews, news items, academic articles, and } \\ & \text { documentaries (see box } 2 \text { and annex I). We also used the depositions collected (Qi) and the documents } \\ & \text { gathered to develop and validate the translation process associated with the CIB project (see the } \\ & \text { quotations Qi throughout the next sections). }\end{aligned}$




\begin{tabular}{|c|c|}
\hline CRITERION & TECHNIQUE ADOPTED \\
\hline Plausibility & $\begin{array}{l}\text { In order to establish plausibility, diagrams and summary tables were developed and used by us to } \\
\text { make it easier for readers to understand the process of actors-network formation, as well as to } \\
\text { explain the translation processes associated with the trajectory of the CIB project implementation, in } \\
\text { line with the assumptions of ANT as proposed by Callon (1986) and Stanforth (2006) (see sections } \\
5 \text { and 6). }\end{array}$ \\
\hline Criticality & $\begin{array}{l}\text { We sought to highlight the controversies in the case under analysis, such as, for example, the view of } \\
\text { the local government versus the view of the community about the CIB project (see section 6). }\end{array}$ \\
\hline Reflexivity & $\begin{array}{l}\text { We revealed our positions on the case analyzed at the beginning of the Data Analysis section, describing } \\
\text { our activities, views and idiosyncrasies on this issue (see section 3.2). }\end{array}$ \\
\hline
\end{tabular}

Source: Elaborated by the authors.

That said, we can now describe the case and discuss it vis-à-vis our findings.

\section{THE CASE: CIDADE INTELIGENTE BÚZIOS (CIB)}

Lying in the north of the state of Rio de Janeiro, the city of Armação dos Búzios, which is locally known as just "Búzios", is situated in the micro-region of Lagos, about 173 kilometers distant from the state capital (IBGE, 2010). The city comprises an area of $70,278 \mathrm{~km}^{2}$ and a population of approximately 27.560 inhabitants (IBGE, 2010). Búzios became recognized as an emancipated city in 1995 - until then, it was considered a district of the Municipality of Cabo Frio (Guimarães, 2015).

The economy of Búzios revolves around the oil royalties, real state and tourism, which is commonly appointed as the city's "vocation"(Freitas, 2014). Indeed, Búzios is internationally recognized as one of the most coveted tourist-spots in Brazil due to its extremely beautiful sunny beaches, its sea and exuberant nature (Guimarães, 2015). Every year the city attracts a varied audience of national and international tourists, which inject currency in Búzios, boosting its economy. For instance, Búzios City Hall has estimated that 150.000 tourists have spent the 2015's New Year's Eve in the city (Ascom, 2015), thereby multiplying several times the number of people in the municipality in a matter of just a few days.

In 2011, an electricity distribution dealer under the Enel Brasil holding - Ampla Energia e Serviços S.A. - launched a project (Cidade Inteligente Búzios - CIB) that aimed at transforming Armação dos Búzios in the first smart city of Latin America (Fortes et al., 2015). Accordingly, this company decided to make the town a smart city lab, similar to the ones that exist in Málaga (Spain) and Masdar (Abu Dhabi) (KPMG, 2012).

The CIB project was originally proposed as a response to federal regulatory requirements of the Brazilian electricity market. In fact, since 2000, electricity distribution dealers that operates in Brazil, such as Ampla, are required by law to invest annually, at least $0.75 \%$ of their net operating revenue in $R \& D$ projects (Aneel, 2012). These substantial financial resources can be spent on the company's own R\&D sector or to sponsor studies carried out on universities and research centers. Moreover, these investments are regulated by the National Electricity Agency (Aneel), a special government regulatory agency attached to the Ministry of Mines and Energy. In order to comply with this 
obligation, companies must send their projects to Aneel. When the project closes, Aneel carries out a careful evaluation of the results achieved and the expenses incurred to decide whether to approve it totally or partially, recognizing (or not) the investments made (Aneel, 2012).

Besides, from time to time, Aneel opens a call for a specific type of R\&D project, named strategic project. Such strategic projects comprise studies and developments that coordinate and integrate the generation of new technological knowledge in a sub-topic of great relevance for the Brazilian electricity sector (Aneel, 2012). In effect, these calls concern more complex and expensive R\&D projects, as supported by I8 in the deposition below: "Strategic projects are huge projects... Sometimes the electricity distribution dealer needs to spend more money... 'Oh, I need to spend 50 million..., then they develop a strategic project" (Q1).

Recognizing a worldwide trend in the electricity sector towards the implementation of smart grids (SG), ANEEL promoted in 2010 a public call for the implementation of a Strategic R\&D Program named "Programa Brasileiro de Redes Inteligentes" (Aneel, 2010). Such program aimed at a technological migration of the Brazilian electricity sector from the current stage to the full adoption of the SG concept throughout the country.

Therefore, Ampla registered CIB at Aneel on 10/31/2011 as a strategic project. The CIB was carried out between November 2011 and October 2016, and costed more than 20 million dollars. More than a half of this amount was sponsored by the financial resources Ampla had to invest by law in R\&D.

\section{IMPLEMENTATION OF CIB VIA ANT}

In order to examine the $\mathrm{CIB}$ case, we adopt the four interrelated moments of translation namely: problematization, interessement, enrolment, and mobilization (Callon, 1986).

\subsection{PROBLEMATIZATION}

Aligned with the concept of problematization (Callon, 1986), Ampla hypothesized to deploy the smart city project in Búzios, based on initial meetings of the project as well as on the information presented in the Aneel's public call for strategic R\&D projects on smart grids.

On August 2011, Ampla submitted a project proposal named Projeto Cidade Inteligente Búzios for the initial evaluation of Aneel. This proposal envisioned an achievement of valuable knowledge regarding SG implementation costs, operation, infrastructure, economic and socio-environmental impacts, adaptability of equipment and identification of new lines of technological development. In addition, Ampla argued that SGs represent the main element for the development of smart cities. As such, this project would fall within the international concept of smart city as sustainable, rational and efficient (Ampla, 2014). The pilot project had a wide scope with relevant investments and the participation of nearly 40 professionals. As such, on October 2011, Aneel issued a favorable opinion and shortly after Ampla started to implement the CIB.

At the institutional website, the CIB project is defined as follows:

The construction of the future begins today. With innovation, technology and sustainability, Ampla is preparing to overcome challenges and build a better world. Búzios is an internationally 
recognized tourism destination and was chosen to house a new model of energy management. A smart network is being installed that will integrate traditional technologies with modern digital solutions to improve the flexibility of the electrical system and information management. In this smart city, the citizen is at the center of transformation [Ampla, 2014]

Beyond complying with Aneel's regulations defining minimum R\&D investiment levels, Ampla's objectives with the CIB project also included taking advantage of the project's potential benefits (technical, financial, and operational), improving the company's technological capability and acquiring experiences, which could be replicated in other areas of Ampla's concession in Brazil, thereby strengthening their relationship with their customers.

According to Callon (1986), throughout problematisation, the initiator defines the interests and the roles of the other actants; the defined interests should be consistent with those of the initiator. In the case of the CIB project, Ampla (the initiator) sought to define the interests and the roles of Buzios' mayor, external institutions (university and research centers) and the city's inhabitants that were also Amplas' customers.

Since the beginning, Ampla assumed that their project would make Búzios a living lab for tests and trials of new technologies and services (KPMG, 2012). As such, Ampla intended to attract external research institutions (university or research center) avid for generating scientific and technical knowledge and able to execute the technological developments proposed by the project (Ampla, 2014).

Furthermore, to implement the project in Búzios, Ampla would need some approvals and the engagement of the city's mayor. Meanwhile, Ampla hypothesized that, as a political leader, the mayor would like to be associated with the smart city project, as well as with the benefits that same could bring to his voters.

At last, in the projects' definition of smart city, the citizens (Ampla's customers) should be at the center of the city's transformation. Therefore, Ampla also mapped Búzios population as an actor. It is important to observe that, at this point, the population was more of an abstract entity interested in enhancing Búzios' quality of life via the CIB project implementation.

In summary, during the problematization phase, Ampla wanted to attend Aneel's public call for R\&D projects on SG while improving the company's technological capability. Thus, they introduced the CIB as an indispensable tool to achieve this goal and built a multidisciplinary team with the objective of systematically monitoring the project. In addition, in the implementation of project, the identities of the other actors - external research institutions, the mayor and the population - were defined. In this way, as shown in figure 2, Ampla defined CIB as an Obligatory Point of Passage (OPP), for which the other actors should move in order to achieve their goals and, consequently, the successful implementation of the CIB project. The following statement set forth by I1 from Ampla supports what was said above: "The CIB project must be at the center of our operation here in Búzios. We need to engage all stakeholders in this endeavor by creating outcomes that interest them. I want that in a near future all community feel the CIB project as indispensable for their lives" (Q2).

Thus, in box 4 we set forth the depositions (Qi) unveiled by the intervieews (Ii), depicting how they support the figure 2 development. 


\section{FIGURE 2 PROBLEMATIZATION PHASE OF THE CIB PROJECT}

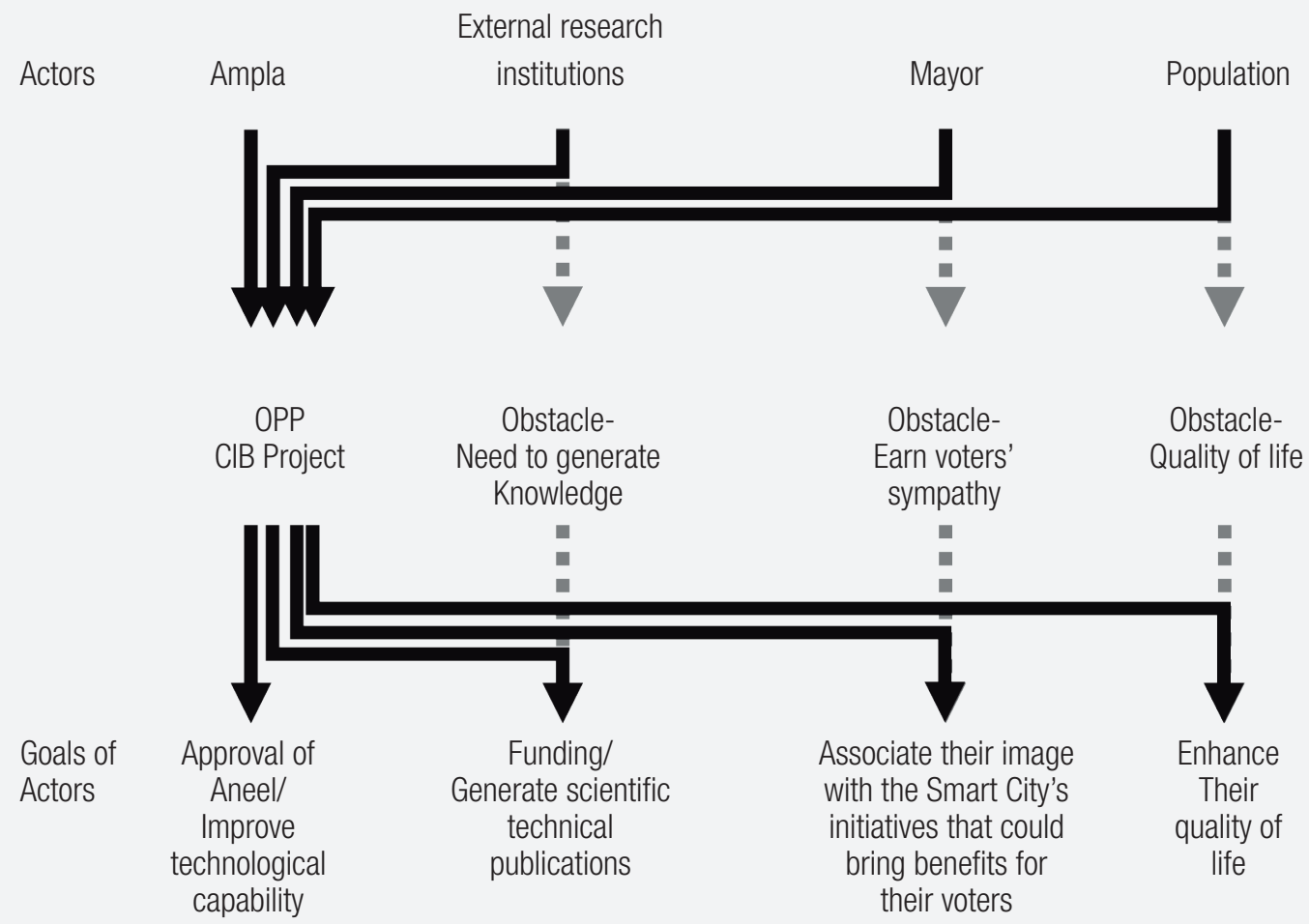

Source: Elaborated by the authors.

BOX 4

DEPOSITIONS SUPPORTING THE PROBLEMATIZATION PHASE OF THE CIB PROJECT

\begin{tabular}{|c|c|c|}
\hline ACTORS & GOAL & REFERENCE \\
\hline AMPLA & $\begin{array}{l}\text { Approval of Aneel } \\
\text { Improve technological capability }\end{array}$ & $\begin{array}{l}\text { Q3: "Ampla has a lot of ideas to be implemented } \\
\text { in Búzios but we do need to have our proposal } \\
\text { approved by Aneel to develop it." (I1) } \\
\text { Q4: "One of Amplas's interest on the CIB project } \\
\text { is to develop new technological capabilities. I } \\
\text { guess that the smart grid initiative will help us to } \\
\text { do that." (110) }\end{array}$ \\
\hline $\begin{array}{l}\text { EXTERNAL RESEARCH } \\
\text { INSTITUTIONS }\end{array}$ & $\begin{array}{l}\text { Generate scientific and technical } \\
\text { publications }\end{array}$ & $\begin{array}{l}\text { Q5: "Our objective here is to develop new } \\
\text { technologies, patented them and use same in } \\
\text { other projects." (18) } \\
\text { Q6: "We have a great opportunity here to develop } \\
\text { scientific articles and publish them in journals. We } \\
\text { are sure that the impact factor of our research } \\
\text { here will be very high." (19) }\end{array}$ \\
\hline
\end{tabular}




\begin{tabular}{|c|c|c|}
\hline ACTORS & GOAL & REFERENCE \\
\hline MAYOR & $\begin{array}{l}\text { Associate his image with the smart } \\
\text { city's initiatives in order to bring } \\
\text { benefits to his voters }\end{array}$ & $\begin{array}{l}\text { Q7: "It was obvious for me and other guys here } \\
\text { in the secretary that the mayor was trying to } \\
\text { take advantage of the CIB project for political } \\
\text { purposes. After all, he was looking forward to be } \\
\text { re-elected in the next pool." (I11) }\end{array}$ \\
\hline POPULATION & Enhance their quality of life & $\begin{array}{l}\text { Q8: "I work in the hotel sector. So, I do hope this } \\
\text { project can foster the tourism in Búzios. This will } \\
\text { certainly increase our quality of life." (118) } \\
\text { Q9: "I do not know exactly what is this project } \\
\text { about, but I expect it can solve several problems } \\
\text { we have had in the city for a long time." (I21) }\end{array}$ \\
\hline
\end{tabular}

Source: Elaborated by the authors.

\subsection{INTERESSEMENT}

After formulating hypotheses about the identities of the actors and their objectives, Ampla developed a series of "interessement devices" to convince the other actors that the interests defined by the company were in fact well in line with their own interests.

Since July 2011, Ampla's public relations engaged in announcing the company's intention of making Búzios the first smart city in Latin America. The project was launched in a pompous event at the Guanabara Palace (Rio de Janeiro's state government headquarter), with the participation of the governor and vice-governor, the then mayor of Buzios and the CEO of Ampla. There, it was signed an agreement between Ampla, Buzios City Hall and the state government (Sicsu, 2011).

Soon, the CIB project and its potential outcomes were highlighted in the national media coverage. Moreover, in 2012, KPMG ranked the CIB as one of the top ten most innovative urban infrastructure projects in the world (KPMG, 2012). Given this positive visibility of the project, it was no surprise for us the mayor's intention to be associated with it, as already noticed via Q7 in box 4. One fact that deserves attention was the misinformation about the project authorship. We have collected several 2011 and 2012's newspapers and magazine reports suggesting that the project was headed by the Búzios' mayor at that time. ${ }^{2}$

In order to execute the project, Ampla defined nine research blocks (as shown in box 5) and created internal teams responsible for each of these blocks. In addition, external institutions (universities or research centers) were invited/hired to develop research within these nine blocks.

\footnotetext{
1 "Interessement devices" are also called "inscriptions" in the ANT vocabulary (Alcadipane and Tureta, 2009).

${ }^{2}$ ALVES, Maria E. Projeto Cidade Inteligente implantado em Búzios é destaque em ranking internacional. O Globo, Rio de Janeiro, 7 Aug. 2012.

CAVALCANTE, V. Sebrae premia prefeitos mais empreendedores do Estado do Rio. Imprensa RJ, Rio de Janeiro, 25 Apr. 2012.

COMUNICA BÚZIOS. Sebrae RJ elege Mirinho Braga o segundo maior prefeito empreendedor do Estado. COMUNICABUZIOS, Rio de Janeiro, 26 Apr. 2012. Available at: <https://comunicabuzios.wordpress.com/2012/04/26/ sebrae?rj?elege?mirinho?braga?o?segndo?maior?prefeito?empreendedor?do?estado >. Accessed on: 24 Apr. 2016.

CRISTIANE, Renata. Inauguração posto Consciência EcoAmpla em Búzios. RC24H, Rio de Janeiro, 19 Apr. 2012. Available at: <http:// rc24h.com.br/noticias/ver/2250/inauguracao-posto-consciencia-ecoampla-em-buzios>. Accessed on: 24 Apr. 2016.
} 


\begin{tabular}{|c|c|c|c|}
\hline Research Block & \multicolumn{3}{|c|}{ External institution } \\
\hline Automation Network & \multicolumn{3}{|c|}{ Lactec/Praex } \\
\hline Distributed Generation & \multicolumn{3}{|c|}{ Coppe/UFRJ } \\
\hline Efficient Public Lighting & \multicolumn{3}{|c|}{ Coppe/UFRJ } \\
\hline Smart metering & FEC/UFF & Landis+GYR & PUC-RIO \\
\hline Smart Buildings & \multicolumn{3}{|c|}{ Coppe/UFRJ } \\
\hline Social Integration and Development & FGV & \multicolumn{2}{|c|}{ Cieds } \\
\hline Systems and Telecommunication & \multicolumn{3}{|c|}{ Lactec/Praex } \\
\hline Electric Vehicles & Cefen/Uerj & \multicolumn{2}{|c|}{ Coppe/UFRJ } \\
\hline
\end{tabular}

Source: Ampla's report sent to Aneel (2016)

Yet, according to an Ampla's employee at the R\&D and Innovation sector (I10), despite the definition of the abovementioned technical blocks, the company wanted the CIB project to be regarded and managed as only one (unique) project): "Ampla wanted to be the hub of the project. We wanted to be in charge of all activities of the project and wanted that the population saw CIB as a unique enterprise" (Q10).

Therefore, they developed an integration structure of the research blocks as depicted in figure 3.

\section{FIGURE 3 INTEGRATION STRUCTURE OF THE RESEARCH BLOCKS}

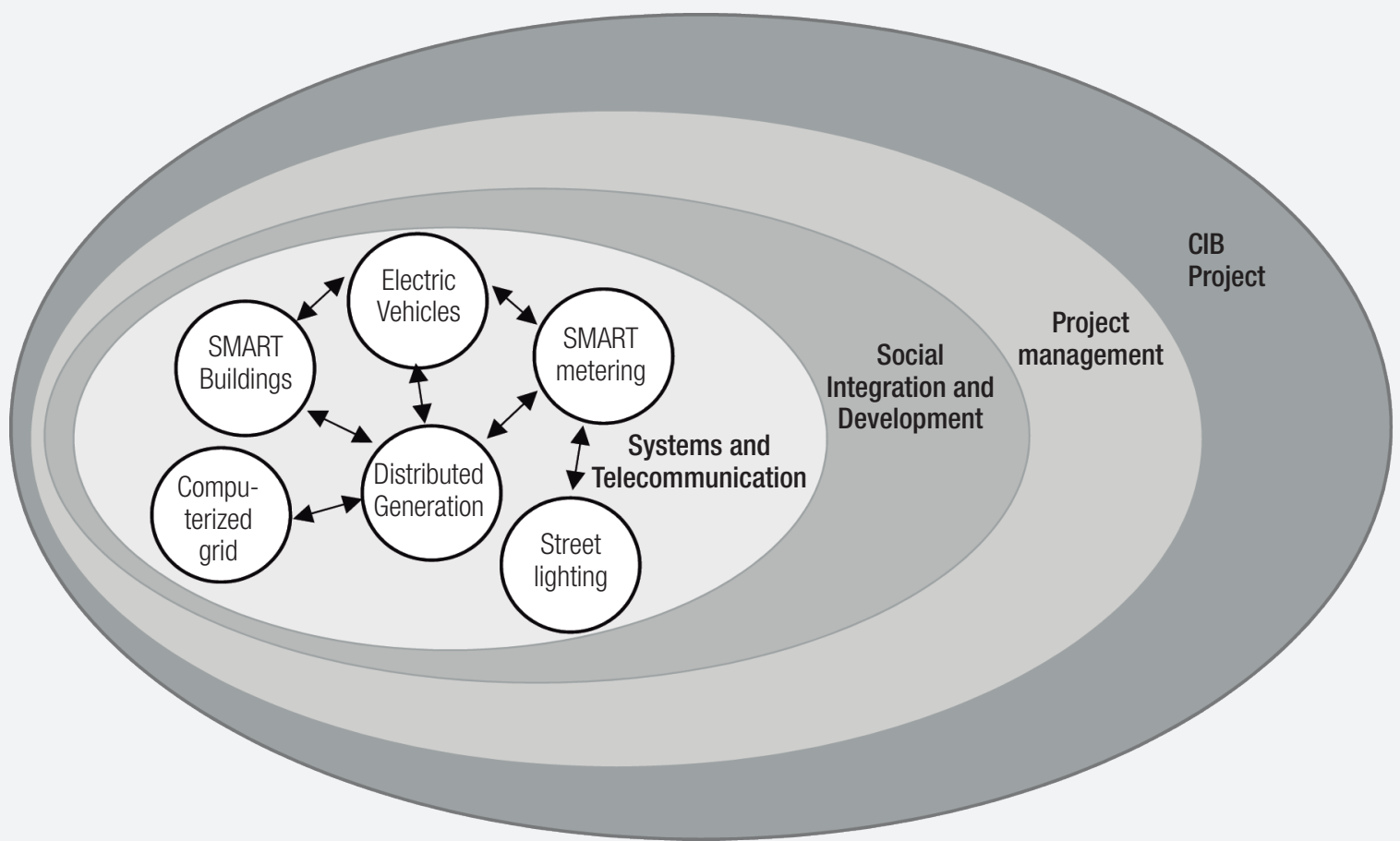

Source: Ampla’s report sent to Aneel (2016). 
As shown in figure 3, some research blocks were linked to or dependent on other blocks, requiring cooperation among the external institutions. In order to promote this cooperation, besides sponsoring the research, Ampla adopted an open data policy, allowing the project's data to be used to generate scientific and technical publications, as can be noticed in deposition below set forth by I1: "Regarding the CIB project, we decided in Ampla to adopt an open data policy for all stakeholders in order they can use our data to produce research, as well develop a collaborative setting" (Q11).

With the purpose of better define the role of the local population in the CIB project, the social development block organized a seminar in March of 2012 to mature the project's concept of smart city. They defined that Búzios' smart city should go beyond investments in technological innovation, promoting better quality of life, higher popular participation, more transparent public management, and higher environmental protection. According to the records of this seminar, they would now assume the following concept of smart city:

A smart city is the outcome of participatory citizenship of people proud of being protagonists in technological integration process that favors sustainable development. The city reinvents itself from a new social, environmental and economic awareness, promotes well-being and is happy. ${ }^{3}$

As explained by the Enel's Brazilian director of Socioeconomic Development and Sustainability sector (I2): "When you make a change, bringing technology into an urban area, you are certainly affecting people's lifestyles, local economy... you affect a number of things. And if these people, the community, are not involved, they might reject it" (Q12).

At this point, with the role of the population better defined, Ampla hired one of the abovementioned external institutions, Centro Integrado de Estudos e Programas de Desenvolvimento Sustentável (Cieds) to develop an "interessement device" able to engage the population in the smart city project, named sustainable network of relationships. Such network would work as a channel of continuous communication and articulation around the issues concerning the development of Búzios as a smart city. A special attention was given for the enhancement of city's social capital, sustainability and innovation matters. Several local actors were involved in this network, such as associations and NGOs. As explained by I3: "So, the idea was to foster a network of information sharing about the process that was happening, to take advantage and to be able to give an opinion" (Q13).

\subsection{ENROLMENT}

"Interessement achieves enrolment if it is successful" (Callon, 1986:206). After introducing the interessement devices or inscriptions, Ampla began to test their hypotheses formulated in the problematization phase regarding the project as well as the actors.

Ampla's assumption that the mayor would want to be involved in the CIB project was initially right. Indeed, according to our observations, the mayor was always available to meet and discuss the project with the company. In fact, he insisted in host Ampla's managers and escort them in every technical

${ }^{3}$ Report entitled "Motivação do Bloco Integração e Desenvolvimento Social" (Ampla, 2015). 
visit they made to Búzios. On the other hand, the company started to improve the city infrastructure by changing some of the street lightening to LED technology luminaries, installing the smart meters and fostering the recycling practices.

One of the first initiatives that gave visibility for the smart city project within the city was the opening ceremony of the Consciência EcoAmpla station, attended by Ampla's managers, the mayor of Búzios and the Buzios' secretary of environment. The Consciência EcoAmpla idea was to promote the practice of recycling in the city. Ampla would exchange recyclable waste for rebate in electricity bills. Thus, in April of 2012, a waste collection station was opened in the city garden, where not only the residents but also the commerce and the hotels could deliver their recyclable garbage, gaining discounts in their electricity bills.

Also in 2012, Ampla built in Búzios a monitoring and research center (headquarter of the project), which functioned as a laboratory as well as a visitation and exhibition center of services and devices developed by the CIB project. The opening event of this center was attended by the president of Ampla, the president of Aneel and the mayor of Búzios. Moreover, journalists, businesspersons and investors were also invited to this ceremony, so they could get to know the project that would transform Búzios "in the first Latin American smart city".

Until the opening ceremony of the monitoring and research center, 222 smart energy meters (of a total of ten thousand aimed by the project) and 60 LED luminaires for public lighting (of a total of 150) had already been installed. Moreover, some points for generation of renewable energies (solar and wind) were working. At the monitoring center, there was an electric recharging station, one car and two electric bicycles for initial tests. In addition, visitors and residents could enjoy a free wi-fi internet access in Rua das Pedras, the city's most popular spot.

However, Ampla was not able to predict that the then mayor of Búzios would not be re-elected as mayor at the 2012's elections, compromising the City Hall engagement achieved so far. As explained by I1: "The project began in the previous mayor government, and the mayor who won the 2012's elections was from the opposition party. So, to be honest, for him it would be good if the project failed" (Q14).

Thus, in 2013, Ampla not only lost the engagement of the City Hall but also had to face the new mayor's resistance. For instance, as soon as the new government took office, they tried to sabotage the Consciência EcoAmpla station. As told by I4:

The City's Environment Secretariat staff who worked at the station kept on a notebook the record of the amount of garbage that each person delivered. This information was then delivered to Ampla so that they could refund the corresponding electricity bills. Shortly after the new government took office, people noticed that they didn't received the expected discounts on their bills. People complained a lot and the Ampla's garbage recycling program became discredit. But what really happened was that the notebook with people's garbage record disappeared and Ampla was misinformed by the secretariat about the discount they should give in each bill. [Q15]

Therefore, the association with the former mayor, defined at problematization backfired. The new mayor refused to play the role ascribed to him. He defined his identity and goal in another manner, thereby requiring Ampla to restart a new series of negotiations. As mentioned by I2: 
We had, of course, established a partnership with the prior government. And when the new government took office, we had a serious problem. The new mayor simply rejected the project because he saw us as political supporters of the former mayor, when in fact we were not. So, until we could convince him that our work (the project) was not political but technical, it took a while. [Q16]

While Ampla was fighting to bring the City Hall back to the project, the Social Integration and Development block of the CIB project was working hard to engage the Buzios' citizens in the project. As observed by I2: "At first, people showed resistance because the quality of our energy supply was very poor. So, people started to ask what Ampla wanted with the project. The relationship was one of mistrust. What is Ampla trying to gain here? It was a very difficult and slow process". (Q17)

In April of 2013, Cieds promoted an event to launch the previously mentioned sustainable network of relationship. Thirty-two local organizations sent their representatives (of the 40 invited) to the meeting, which was also attended by Ampla's team and the local media, totalizing about a hundred people. As I3 remembers: "At first I noticed a mistrust among the people... But after some time and the development of the network, they start seeing the opportunities". (Q18)

Regarding the engagement of external institutions to develop technological research, Ampla assumed right that same would be interested in developing and publishing studies about the CIB project. Cieds managed to engage 238 collaborators and researchers that ended up publishing 52 papers in academic journals and conference proceedings. On the other hand, Cieds had some problem in integrating this research with the Social Integration and Development block. As mentioned by I9:

To be honest, at the beginning I felt a bit anger with the social projects. We, the engineers, are conditioned to think only about the technological side of it. As such, I spent about two weeks in Búzios choosing the roofs better positioned for installing photovoltaic panels. And after all this effort, came the people from Cieds and said that it shouldn't be that way and that we should also think about the legacy of the project for the local community. Therefore, despite not being the better positioned roofs, we should look for buildings such as public schools and favor them with our technology. We had to make some changes in our projects but at the end I was already thinking differently. I think it was very nice to get in touch with the local community and acknowledge that a smart city is not only about capitalism and technology. [Q19]

Therefore, due to the local context, the cooperation among the blocks involved some negotiations. Ampla developed regular follow-up workshops about the project, wherein the representatives of each research block were supposed to share their achievements and the troubles they were facing. Such meetings ended up being powerful inscriptions to build a CIB team spirit, as well as reinforce the research institutions role in the network.

\subsection{MOBILIZATION}

Who speaks in the name of whom? Who represents whom? According to Callon (1986), these crucial questions must be answered if the project led by Ampla is to succeed. As mentioned before, Ampla 
first stablished a relationship with the then mayor of Búzios. Once he was not re-elected at the end of 2012, he could not speak in the name of Buzios' City Hall anymore. In fact, Ampla's association with the prior mayor harmed the project development. Consequently, Ampla had to work even harder, not only to establish a new relationship with the new mayor, but also erase the traces left by the association with the former one. As such, the project managers started to define the smart city project as apolitical, aiming only the benefit of the Búzios' population, as we can notice via the aforementioned deposition Q16.

In the end, Ampla managed to have some City Hall acceptance, but not a full engagement as it initially had. For instance, we realized that the new mayor of Búzios let Ampla install photovoltaic panels in three municipal schools, which in turn would reduce the schools' electricity bills. Meanwhile, Ampla delivered a series of lectures about energy efficiency and the CIB project to the schools' teachers and students. In April of 2014, the mayor attended an event promoted by Ampla, where the company donated six electric bicycles of the CIB project to be used by the City Hall' s fighting initiatives against dengue (an infectious tropical disease).

On the other hand, we perceived that the now mayor of Búzios never encouraged his secretariat to attend the sustainable network meetings, nor gave any credit to the work developed within these meetings. According to I15, the representative of an organization at the network, the City Hall main issue with it was that Búzios' public authorities started to perceive them (the people within the network) as their competitors.

When the network meetings started to raise a lot of fresh ideas, as the development of a new environmental plan for the city, they [public authorities] were not very happy. These were valuable ideas for developing the city, but they wouldn't take the credit for it. Many plans developed by the network were never put in practice. [Q20]

Regarding the population, they were supposed to be represented by the sustainable network of relationships developed by Cieds. Even though the network claimed to represent the Buzios' citizens, we realized that it was not able to spread the smart city idea and its benefits throughout the population. More than once, we have asked people in Buzios about the CIB project and they could not explain us what it was about. For instance, I11, a local resident, answered as follows: "I don't know what it is or how it works. They talk about it (smart city) but they do not explain what it is. It sounds like something that only interests the educated and wealthy people”. (Q21)

Finally, the external institutions representatives in the CIB project successfully assured the engagement of their collaborators. All the blocks manage to develop their part of the research and in the closing ceremony of the project, the following tangible achievements were presented by Ampla: ${ }^{4}$

- The network automation has contributed to improve the quality indicators, reducing the nondistributed energy;

${ }^{4}$ Presented at the closing event of the CIB project held on December 08, 2016, at the project's monitoring and research center in Búzios (Rio de Janeiro). 
- Local power generation near the place it is consumed has reduced technical losses in distribution;

- Answering customers' demand with renewable energy sources has allowed to reduce investments in network expansion;

- Remote metering and billing have reduced the cost of locally reading the meters;

- The possibility of electric power cuts and remote reconnection have reduced expenses with field teams;

- Greater awareness of energy consumption has promoted energy efficiency with an impact on the cost of network expansion.

It is also worth mentioning that although ANEEL have not yet issued a final verdict about the CIB project, Ampla and the researchers involved in the project were certain that the agency would accept the investments made, as we can see in the deposition of I9 and I10, respectively: "Ampla is sure that Aneel will accept our investments as the project has brought several benefits for the city's population" (Q22); "We have developed state-of-art research in this project. I am sure ANEEL will issue a positive opinion on the project" (Q23).

\section{DISCUSSION}

Using a detailed case study of the CIB project, we tried to provide a rich description of the trajectory of a smart city project in a developing country. As observed in previous section, the CIB project followed what Tironi and Sánchez Criado (2015) called the most common development strategy adopted in smart cities. Indeed, the CIB project, regarded as a pilot study, allows a large company (Ampla) to test technological and service prototypes. Moreover, it was carried out as an urban laboratory to test and demonstrate the durability and social integration of their products and services.

In turn, the urban laboratory strategy involved unavoidable risks, generated by new and untested trials (Nam and Pardo, 2011). Consequently, during CIB's implementation, we perceived the emergence of several controversies and situations not foreseen at the project planning stage. Moreover, we also observed that, meanwhile one actor (external research institutions) kept intact its relationship and role as planned by Ampla, the others did not follow the company's lead throughout the entire implementation of CIB. We can, thus, analyze these associations and connections via the translation process, as shown in figure 4.

During the project implementation, we observed that for the actors perform their roles as assumed at the problematization stage, Ampla sought to develop interessement devices (called inscriptions). The company's objective of enriching their technological capability and Aneel's recognition of the R\&D investments were met. However, Ampla's intention to improve its relationship with the population (Ampla's customers) seems to have failed, as we can notice from the following deposition made by I11, a local resident: "For me, this project is just marketing. Our comunity has had a bad relationship with Ampla. Al in all, what they want is to make money on us" (Q25).

Therefore, despite the heavy corporate investment in promoting the CIB project and the numerous research findings, it remains for us the question whether Búzios has been actually transformed into a smart city. This is indeed a complex issue as regards different points of view. Ampla would say yes, as the company states through official documents that the project has brought many benefits for the city, enhancing Búzios' citizens' quality of life, as we can see at the deposition below unveiled by I1: 
"It is true that we had to overcome several problems in this project but it's undoubtedly that a lot of benefits for the local population have accrued from it" (Q26).

\section{FIGURE $4 \quad$ GRAPHIC REPRESENTATION OF TRANSLATION STAGES}
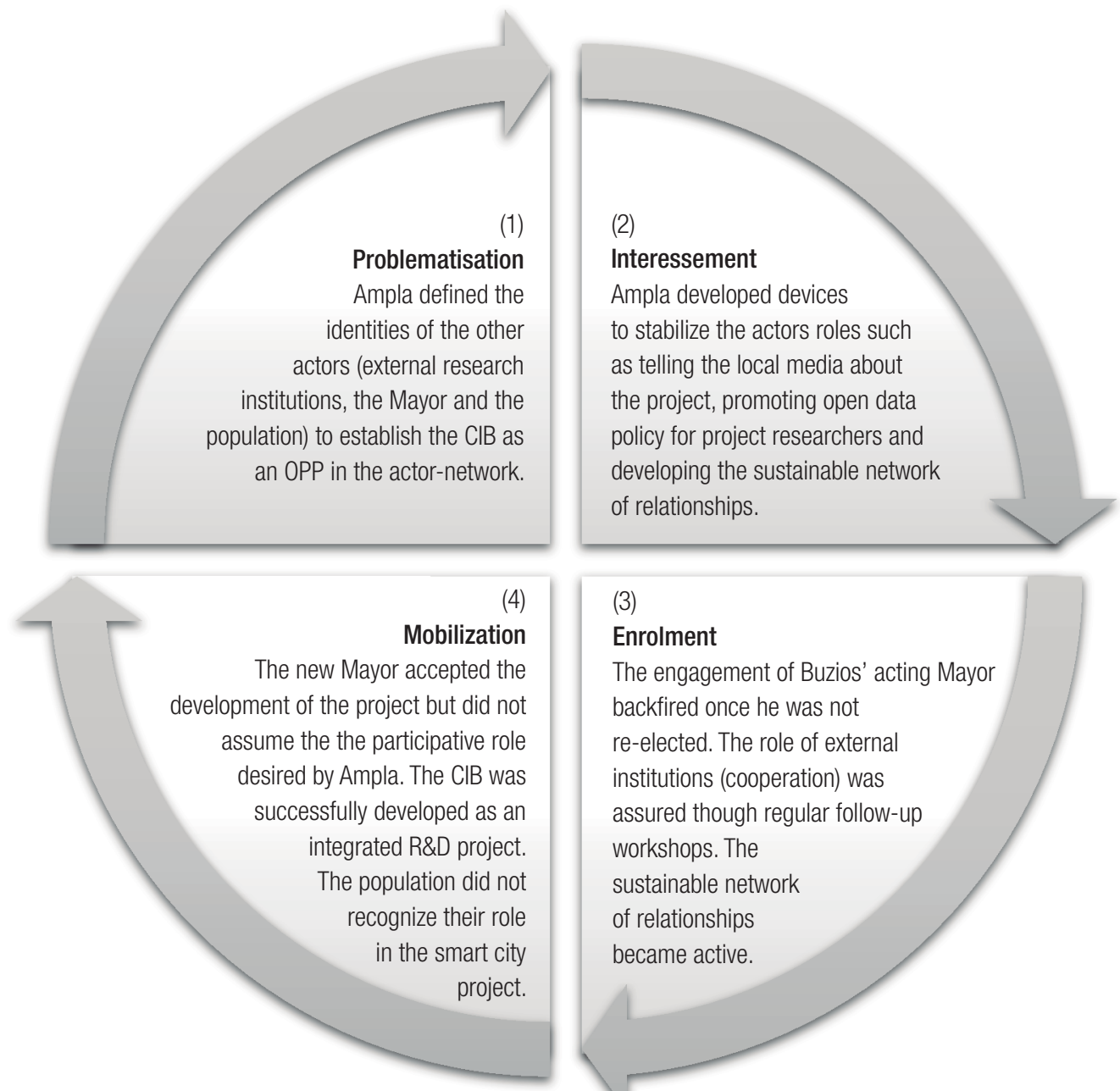

(3)

Enrolment

The engagement of Buzios' acting Mayor backfired once he was not re-elected. The role of external institutions (cooperation) was assured though regular follow-up workshops. The sustainable network of relationships became active.

Source: Elaborated by the authors.

On the other hand, by the end of the project, Búzios' public authorities do not truly recognize the success of the project. They identify some Ampla's deeds that favored the city but they do not call Búzios a smart city. The deposition below set forth by I12 addresses this issue: "Ampla promised us several technological innovations to be implemented in our city. Yet, at the end, very few innovations have been perceived by the local community and even for us that belong to the municipal government" (Q27).

At last, we realized that the citizens, which according to Ampla were supposed to be at the center of the transformation, seemed to have stayed quite unaware of the project implementation. Even 
their representatives that were in the sustainable network of relationships have apparently disengaged from the project. Since Cieds left the network management, the network members got lost and have striven to keep the network alive.

In fact, we noticed that the potential positive impact of the sustainable network of relationships for Búzios faded away with the resistance of city's political leaders, as the political administration changed in the course of CIB's project. The new political leaders saw the partnerships and interdependence of local actors as a threat to the hierarchical modes of the bureaucratic state and the dependence on public policy makers to define the future of the city (see the aforementioned depositions Q14, Q15 and Q16). As most of the network initiatives needed the government to enable their development, they were never implemented. As such, the local government and the community demonstrated no more interest on the CIB project and by consequence disengaged from this initiative, which led to the demobilization of the sociotechnical network presented in figure 2.

Thus, as we have shown via this this case study, to smart city initiatives become sustainable it needs to include both "hard" and "soft" domains. While we can observe some technological and social benefits left by Ampla for the city of Búzios, we realized that the web associations were not strong enough to make Búzios smart city project a closed and sustainable socio-technical network.

\section{CONCLUDING REMARKS}

We developed this study to understand the role of context in the deployment of smart city initiatives. As such, by using Actor-Network Theory (ANT), we have put forth the different stages of a smart city project developed in the city of Búzios. We ended up with a story about active builders of actornetworks and also about how the actor-network grows, changes and stabilizes (or not) over time. Yet, we concluded that all of this is dependent on the context, which varied very much over the CIB project implementation. The political interests changed with the election of a new and opposition municipal government, which started to jeopardize the smart city project. This new administration did not see the CIB project as an OPP and by consequence started to disengage from the project. As such, the political context must not be disregarded in smart city implementations. This is a very important issue in a country like Brazil where public policies discontinuity (Frey, 1999) and political fragmentation (Palermo, 2000) is rather a rule than an exception.

Moreover, we concluded that the local community although showing initial interest on the project, also disengaged from same as the project managers and the local political administration failed to involve them. Thus, we realized that for most of the local community the CIB project was simply irrelevant. These facts demobilized the socio-technical network developed around the CIB project and unveiled again how important the local context is in the implementation of smart city endeavors, being this a contribution of this article for public policies regarding the deployment of intelligent cities. We may see a similar outcome in the Barcelona smart city project, which was mainly based on environmental issues. According to March and Robera-Fumaz (2016), the Barcelona municipal administration perceived after a while the very need to repoliticize the moots on this smart city project, aiming at putting citizens back at the center of the urban debate. Conversely, in Brazil, Curitiba is an example of political continuity associated with the smart city initiatives, which led the city to develop a sustainable smart city endeavor mainly based on smart transportation (Weiss et al., 2017). The same 
can be said to Singapore, where the absolute political stability conveyed the country to one of the most successful smart city enterprises (Mahizhnan, 1999). In sum, we can conclude that besides the investments in technological improvements, the public authorities and the population representatives need to be active actors through such urban transformation, in order to build a sustainable smart city environment, as also supported by Madeira and collaborators (2017).

This article also came up with some academic contributions for the smart city knowledge area. First, we tried to attend the call for more empirical studies on smart cities, as claimed by Glasmeier and Christopherson (2015). Second, we unveiled a critical analysis on the "technocentricity" of smart city enterprises and set forth that the context should be taken into consideration, as also supported by Avgerou (2001). Third, smart cities have been regarded as the innovative solution to solve contemporary cities' problems raised by the ever-increasing urban population. Nevertheless, in this present study we have shown that the real benefits of smart city initiatives are not clear cut, as also supported by Greenfield (2013) and Luque-Ayala and Marvin (2015). In other words, we noticed that the very concept of success in smart city implementations must be better defined, in order to answer: "success for whom?" This duly complies with the conclusions arisen by Melon (2016), who said that projects success is mainly linked to the customer (or citizen) satisfaction rather that to scope, time, cost and quality.

One limitation of this research involves the methodological challenge we had to face generated by the choice of Actor-Network Theory as our research approach. This was due to the time constraints and lack of funds necessary for the actor-network to be studied and followed, as well as to identify the associations within the same over the network construction process. Besides, a further limitation is related to the very nature of ANT, since, according to Heeks and Stanforth (2015), ANT is considered by some authors to be a descriptive theory based merely on narrative. However, even though it has a major descriptive character, we pursued to unveil the critical role of context over the translation process associated with the smart city implementation project under analysis.

Likewise, Actor-Network Theory follows the critical-interpretive paradigm (Pozzebon, 2004; Alcapadini and Tureta, 2009). Due to this, ideological neutrality is not possible in ANT studies, thereby being necessary to disclose the ideological motivations of the project's stakeholders, as well as of ourselves - the researchers. Although conscious attempts were made by us to achieve neutrality throughout our paper development, it is possible that some bias has remained in our article.

Finally, to further understand the CIB project, we suggest a follow-up study to be developed in a few years in order to find out the more relevant traces left by the project, assessing whether and how such traces have actually affected the city. 


\section{REFERENCES}

ALCADIPANI, Rafael; TURETA, César. Teoria ator-rede e estudos críticos em administração: possibilidades de um diálogo. Cadernos EBAPE.BR, Rio de Janeiro, v. 7, n. 3, p. 406-418, 2009.

AMÉRICO, Bruno L.; TAKAHASHI, Adriana R. W. Conhecimento, aprendizagem organizacional e poder na rede: um estudo de caso na Secretaria de Educação e Cultura de Coahuila, México. Rev. Adm. Pública, Rio de Janeiro, v. 48, n. 2, p. 411-437, Mar./Apr. 2014.

AMPLA. Cidade Inteligente Búzios. 2014. Available at: <www.cidadeinteligentebuzios.com.br/ institucional/>. Accessed on: 31 Mar. 2016.

AMPLA. Motivação do Bloco Integração e Desenvolvimento Social. Niterói: s.n., 2015.

ANDRADE, Andre S. C. G. Trajetórias de implantação do Projudi à luz da teoria ator-rede. 2013. Thesis (Doctor Degree) - Escola Brasileira de Administração Pública e de Empresas, Fundação Getulio Vargas, Rio de Janeiro, 2013.

ANEEL. Chamada no 011/2010 - Projeto estratégico: Programa Brasileiro de Rede Elétrica Inteligente. Brasília: Agência Nacional de Energia Elétrica, 2010.

ANEEL. Manual do programa de pesquisa $e$ desenvolvimento tecnológico do setor de energia elétrica. Brasília: Agência Nacional de Energia Elétrica, 2012.

ASCOM. Réveillon de Búzios terá queima de fogos e festa com DJs. Búzios: Prefeitura, 2015. Available at: $<$ http://buzios.rj.gov.br/noticia/reveillon-de-buziostera-queima-de-fogos-e-festa-com-djs-2>. Accessed on: 4 Apr. 2016.

AVGEROU, Chrisanthi. Information systems in developing countries: a critical research review. Journal of information Technology, v. 23, n. 3, p. 133-146, 2008.

AVGEROU, Chrisanthi. The significance of context in information systems and organizational change. Information Systems Journal, v. 11, n. 1, p. 43-63, 2001.

BAUER Martin W.; AARTS Bas. A construção do corpus: um princípio para a coleta de dados qualitativos. In: BAUER, M.; GASKELL, G. (Org.). Pesquisa qualitativa com texto, imagem e som. Petrópolis: Vozes, 2002. p. 39-63.
BORJA, Rafael; GAMA, Kiev. Middleware para cidades inteligentes baseado em um barramento de serviços. In: SIMPÓSIO BRASILEIRO DE SISTEMAS DE INFORMAÇÃO, 10., 2014, Londrina. Anais... Londrina: SBSI, 2014. p. 584-590.

BULKELEY, Harriet; MCGUIRK, Pauline M.; DOWLING, Robyn. Making a smart city for the smart grid? The urban material politics of actualising smart electricity networks. Environment and Planning, v. 48, n. 9, p. 1709-1726, 2016.

CALLON, Michel. Some elements of a sociology of translation: domestication of the scallops and the fisherman of St Brieuc Bay. In: LAW, John (Ed.). Power action and belief a new sociology of knowledge. London: Routledge, 1986. p. 196-223.

CAMPBELL, John L. et al. Coding in-depth semistructured interviews: problems of unitization and intercoder reliability and agreement. Sociological Methods \& Research, v. 42, n. 3, p. 294-320, 2013.

CARAGLIU, Andrea; BO, Chiara D.; NIJKAMP, Peter. Smart cities in Europe. Journal of Urban Technology, v. 18, n. 2, p. 45-59, 2011.

CAVAlHEIRO, Gabriel M. C.; JOIA, Luiz A. Examining the implementation of a European patent management system in Brazil from an actor-network theory perspective. Information Technology for Development, v. 22, n. 2, p. 220-241, 2014.

CHOURABI, Hafedh et al. Understanding smart cities: an integrative framework. In: HAWAII INTERNATIONAL CONFERENCE ON SYSTEM SCIENCES, 45., 2012, Hawaii. Proceedings... Washington: IEEE, 2012. p. 2289-2297.

DÍAZ ANDRADE, Antonio; URQUHART, Cathy. The affordances of actor network theory in ICT for development research. Information Technology \& People, v. 23, n. 4, p. 352-374, 2010.

DINIZ, Eduardo; BIROCHI, Rene; POZZEBON, Marlei. Triggers and barriers to financial inclusion: the use of ICT-based branchless banking in an Amazon county. Electronic Commerce Research and Applications, v. 11, n. 5, p. 484-494, 2012.

DOOLIN, Bill; LOWE, Alan. To reveal is to critique: actor-network theory and critical information systems research. Journal of Information Technology, v. 17, n. 2, p. 69-78, 2002. 
ENEL. Relatório final: estudo dos efeitos da implementação de tecnologias de redes elétricas inteligentes (smart city) — Projeto Cidade Inteligente Búzios. Niterói: s.n., 2016.

FLEURY, Sonia; SUBIRATS, Joan; BLANCO, Ismael. Respuestas locales a inseguridades globales. Innovación y cambios en Brasil y España. Interrogar la actualidad Serie América Latina. Barcelona: Fundació Cidob, 2008.

FORNAZIN, Marcelo; JOIA, Luiz A. Remontando a rede de atores na implantação de um sistema de informação em saúde. Revista de Administração de Empresas, v. 55, n. 5, p. 527-538, 2015.

FORTES, Marcio Z. et al. Power quality analysis for dg in smart city búzios. In: INTERNATIONAL CONFERENCE ON ELECTRICITY DISTRIBUTION, 23., 2015, Lyon. Proceedings... Lyon: Cired, 2015.

FREITAS, João Alcantara. Cidade Inteligente Búzios: entre paradigmas e percepções. Rio de Janeiro: Fundação Getulio Vargas, 2014.

FREY, Klaus. Análise de políticas públicas: algumas reflexões conceituais e suas implicações para a situação brasileira. Cadernos de Pesquisa, n. 18, p. 211-259, 1999.

FRIESE, Susane. Qualitative data analysis with ATLAS. ti. London: Sage, 2014.

GABRYS, Jennifer. Programming environments: environmentality and citizen sensing in the smart city. Environment and Planning D: Society and Space, v. 32, n. 1, p. 30-48, 2014.

GAMA, Kiev; ALVARO, Alexandre; PEIXOTO, Eduardo. Em direção a um modelo de maturidade tecnológica para cidades inteligentes. In: SIMPÓSIO BRASILEIRO DE SISTEMAS DE INFORMAÇÃO, 8., 2012, São Paulo. Anais... São Paulo: SBSI, 2012.

GIBBS, David; KRUEGER, Rob; MACLEOD, Gordon. Grappling with smart city politics in an era of market triumphalism. Urban Studies, v. 50, n. 11, p. 2151-2157, 2013.

GLASMEIER, Amy; CHRISTOPHERSON, Susan. Thinking about smart cities. Cambridge Journal of Regions, Economy and Society, v. 8, n. 1, p. 3-12, 2015.

GREENFIELD, Adam. Against the smart city. New York: Do projects, 2013.
GREGOR, Shirley. The nature of theory in information systems. MIS Quarterly, v. 30, n. 3, p. 611-642, 2006.

GUIMARÃES, Airton. Búzios/Brasil: inesquecível. Unforgetlable. Inolvidable. Belo Horizonte: Edição do Autor, 2015.

HEEKS, Richard; SEO-ZINDY, Ryoung. ICTs and social movements under authoritarian regimes: an actor-network perspective. In: UK ACADEMY FOR INFORMATION SYSTEMS CONFERENCE, 14., 2013, Oxford. Proceedings... Oxford: Ukais, 2013.

HEEKS, Richard; STANFORTH, Carolyne. Technological change in developing countries: opening the black box of process using actornetwork theory. Development Studies Research, v. 2, n. 1, p. 33-50, 2015.

HRUSCHKA, Daniel et al. Reliability in coding open-ended data: lessons learned from HIV behavioral research. Field Methods, v. 16, n. 3, p. 307-331, 2004.

IBGE. Instituto Brasileiro de Geografia e Estatística. Rio de Janeiro, 2010. Available at: <http://cidades. ibge.gov.br>. Accessed on: 1 Apr. 2016.

KITCHIN, Rob. Making sense of smart cities: addressing present shortcomings. Cambridge Journal of Regions, Economy and Society, v. 8, n. 1, p. 131-136, 2015.

KLAUSER, Francisco R.; ALBRECHTSLUND, Anders. From self-tracking to smart urban infrastructures: towards an interdisciplinary research agenda on big data. Surveillance \& Society, v. 12, n. 2 , p. $273,2014$.

KLECUŃ, Ela. Conducting critical research in information systems: can actor-network theory help? In: KAPLAN, Bonnie et al. (Ed.). Information systems research: relevant theory and informed practice. Boston: Springer, 2004. p. 259-274.

KPMG. Infrastructure 100: world cities edition. Amstelveen: KPMG, 2012.

KRIPPENDORFF, Klaus. On the reliability of unitizing continuous data. Sociological Methodology, v. 25, p. 47-76, 1995.

KURASAKI, Karen S. Intercoder reliability for validating conclusions drawn from open-ended interview data. Field Methods, v. 12, n. 3, p. 179194, 2000. 
LATOUR, Bruno. On recalling ANT. The Sociological Review, v. 46, p. 15-25, 1999.

LATOUR, Bruno. Reassembling the social: an introduction to actor-network theory. Oxford: Oxford University Press, 2005.

LUQUE-AYAlA, Andres; MARVIN, Simon. Developing a critical understanding of smart urbanism? Urban Studies, v. 52, n. 12, p. 2105-2116, 2015.

MADEIRA, Gilberto S.; GUIMARAES, Tor; MENDES, Leonardo S. Construindo governança eletrônica de cidades: um modelo de implementação de soluções para inovação e otimização da gestão pública. Revista de Gestão dos Países de Língua Portuguesa, v. 16, n. 2, p. 55-71, 2017.

MAHIZHNAN, Arun. Smart cities: the Singapore case. Cities, v. 16, n. 1, p. 13-18, 1999.

MARCH, Hug; RIBERA-FUMAZ, Ramon. Smart contradictions: the politics of making Barcelona a self-sufficient city. European Urban and Regional Studies, v. 23, n. 4, 2016.

MARIOTTO, Fabio L.; ZANNI, Pedro P.; DE MORAES, Gustavo H. S. M. Para que serve um estudo de caso único na pesquisa de gestão? RAERevista de Administração de Empresas, v. 54, n. 4, p. 358-369, 2014.

MCCRACKEN, Grand. The long interview. London: Sage, 1988.

MELON, Marcela, The social representation of success in IT projects in Brazil from the IT professionals' perspective. 2016. Thesis (Master Degree) - Escola Brasileira de Administração Pública e de Empresas, Fundação Getulio Vargas, Rio de Janeiro, 2016.

MITEV, Nathalie; HOWCROFT, Debra. Poststructuralism, social shaping of technology, and actor-network theory: what can they bring to IS research? In: GALLIERS, Robert D.; CURRIE, Wendy L. The Oxford handbook of management information systems: critical perspectives and new directions. Oxford: Oxford University Press, 2011. p. 292-323.

MURDOCH, Jonathan. Inhuman/nonhuman/ human: actor-network theory and the prospects for a nondualistic and symmetrical perspective on nature and society. Environment and Planning D: Society and Space, v. 15, n. 6, p. 731-756, 1997.
NAM, Taewoo; PARDO, Theresa A. Conceptualizing smart city with dimensions of technology, people, and institutions. In: ANNUAL INTERNATIONAL DIGITAL GOVERNMENT RESEARCH CONFERENCE ON DIGITAL GOVERNMENT INNOVATION IN CHALLENGING TIMES, 12., 2011, Nova York. Proceedings... New York: ACM Press, 2011. p. 282-291.

NEIROTTI, Paolo et al. Current trends in smart city initiatives: some stylised facts. Cities, v. 38, p. 25-36, jun. 2014.

PALERMO, Vicente. Como se governa o Brasil? O debate sobre instituições políticas e gestão de governo. Dados, v. 43, n. 3, p. 521-557, 2000.

PIRO, Giuseppe et al. Information centric services in smart cities. Journal of Systems and Software, v. 88, p. 169-188, 2014.

POZZEBON, Marlei. Conducting and evaluating critical interpretative research: examining criteria as a key component in building a research tradition. In: KAPLAN, Bonnie et al. (Ed). Information systems research: relevant theory and informed practice. Boston: Springer, 2004. p. 275-292.

RAMAPRASAD, Arkalgud; SÁNCHEZ-ORTIZ, Aurora; SYN, Thant. A unified definition of a smart city. In: INTERNATIONAL CONFERENCE ON ELECTRONIC GOVERNMENT, 2017. Lyon. Proceedings... Lyon: Egovis, 2017. p. 13-24.

RAMOS, Eduardo A. A. Remontando a política pública: a evolução da política nacional de informática analisada pela ótica da teoria do ator-rede. 2009. Thesis (Doctor Degree) - Escola Brasileira de Administração Pública e de Empresas, Fundação Getulio Vargas, Rio de Janeiro, 2009.

SARKAR, Alankrita N. Significance of smart cities in 21st century: an international business perspective. Focus: Journal of International Business, v. 2, n. 2, p. 54-82, 2015.

SEN Amartya. Development as freedom. Oxford: Oxford Paperbacks, 2001.

SICSU, L. Programa "cidade inteligente - búzios" é lançado no Rio de Janeiro. Rio de Janeiro: Subsecretaria de Comunicação Social - Imprensa RJ, 2011.

STAKE, Robert E. Case studies. In: DENZIN, Norman K.; LINCOLN, Yvonna S. (Ed.). Strategies 
of qualitative inquiry. California: Sage Publications, 1998. p. 445-454.

STAKE, Robert E. Multiple case study analysis. New York: Guilford Press, 2006.

STAKE, Robert E. The art of case study research. Thousand Oaks: Sage Publications, 1995.

STANFORTH, Carolyne. Using actor-network theory to analyze e-government implementation in developing countries. Information Technologies \& International Development, v. 3, n. 3, p. 35-60, 2006.

TELES, Adonai; JOIA, Luiz A. Assessment of digital inclusion via the actor-network theory: the case of the Brazilian municipality of Piraí. Telematics and Informatics, v. 28, n. 3, p. 191-203, 2011.

THRIFT, Nigel. The "sentient" city and what it may portend. Big Data \& Society, v. 1, n. 1, p. 1-21, 2014.

TIRONI, Martin; SÁNCHEZ CRIADO, Tomas. Of sensors and sensitivities. Towards a cosmopolitics of "smart cities"? Tecnoscienza: Italian Journal of Science \& Technology Studies, v. 6, n. 1, p. 89-108, 2015.

UNITED NATIONS. World urbanization prospects: the 2014 revision. Department of Economic and Social Affairs - Population Division. New York: United Nations, 2015.
VANOLO, Aalbeto. Smartmentality: the smart city as disciplinary strategy. Urban Studies, v. 51, p. 883898, 2013.

WALSHAM, Geoff. Are we making a better world with ICTs? Reflections on a future agenda for the IS field. Journal of Information Technology, v. 27, n. 2, p. 87-93, 2012.

WALSHAM, Geoff. Interpretive case studies in IS research: nature and method. European Journal of Information Systems, v. 4, n. 2, p. 74-81, 1995.

WEISS, Marcos C.; BERNARDES, R. C.; CONSONI, Flavia L. Cidades inteligentes: casos e perspectivas para as cidades brasileiras. Revista Tecnológica da Fatec Americana, v. 5, n. 1, p. 1-13, 2017.

WEISS, M. C.; BERNARDES, R. C.; CONSONI, F. L. Cidades inteligentes como nova prática para o gerenciamento dos serviços e infraestruturas urbanos: a experiência da cidade de Porto Alegre. Revista Brasileira de Gestão Urbana, v. 7, n. 3, p. 310-324, 2015.

WEISS, Marcos; CONSONI, Flávia. A internetilização das cidades brasileiras e a utopia das cidades inteligentes: uma análise do distanciamento entre o mundo real e o mundo virtual em terra brasilis. International Journal of Knowledge Engineering and Management, v. 6, n. 15, p. 23-50, 2017.

\section{Mariana Brandão}

Master in Administration from FGV EBAPE; PhD in Administration from FGV EBAPE; Adjunct Professor at Unigranrio University. E-mail: mariana.cavalheiro@unigranrio.edu.br.

\section{Luiz Antonio Joia}

Engineer from Military Institute of Engineering; Master in Civil Engineering from Coppe/UFRJ; PhD in Production Engineering from Coppe/UFRJ; Associate Professor at FGV EBAPE. E-mail: luiz.joia@fgv.br. 


\section{ANNEX 1 LIST OF THE DOCUMENTS CONSULTED}

\begin{tabular}{|c|c|c|c|}
\hline Source & Type of document & Date & Title \\
\hline Ampla & Promotional material & 2011 & Cidade Inteligente Búzios \\
\hline Ampla & $\begin{array}{l}\text { Conference } \\
\text { presentation }\end{array}$ & Nov-11 & $\begin{array}{l}\text { Planejamento da Infraestrutura Elétrica do Estado do Rio } \\
\text { de Janeiro para os Grandes Eventos a partir de } 2012\end{array}$ \\
\hline Ampla & Guide & Mar-12 & Motivação do Bloco Integração e Desenvolvimento Social \\
\hline Ampla & $\begin{array}{l}\text { Conference } \\
\text { presentation }\end{array}$ & Nov-13 & Avanços do projeto Cidade Inteligente Búzios \\
\hline Ampla & Press Release & Feb-14 & $\begin{array}{l}\text { Ampla investe em melhorias na rede elétrica e tem } \\
\text { esquema especial para o carnaval } 2014\end{array}$ \\
\hline Ampla & Presentation & Aug-14 & Projeto Cidade Inteligente Búzios \\
\hline Ampla & Report & Sep-15 & Motivação do Bloco Integração e Desenvolvimento Social \\
\hline Ampla & Presentation & Jan-16 & $\begin{array}{l}\text { Projetos de Sustentabilidade — Cidade Inteligente de } \\
\text { Búzios }\end{array}$ \\
\hline Ampla & Final report & Dec-16 & $\begin{array}{l}\text { Estudo dos Efeitos da Implementação de Tecnologias de } \\
\text { Redes Elétricas Inteligentes (Smart City) — Projeto Cidade } \\
\text { Inteligente Búzios }\end{array}$ \\
\hline $\begin{array}{l}\text { Ampla/ West/ UFF/ } \\
\text { PUC-RIO/ UFRJ/ Cefen/ } \\
\text { Furukawa/ Cieds }\end{array}$ & Presentation & Dec-16 & Workshop de encerramento — Cidade Inteligente Búzios \\
\hline Aneel & Report & Nov-13 & Consolidado de projetos de redes inteligentes \\
\hline Aneel & Report & Nov-14 & $\begin{array}{l}\text { Redes Elétricas Inteligentes Diálogo Setorial Brasil-União } \\
\text { Europeia (2014) }\end{array}$ \\
\hline Aneel & Presentation & Jun-15 & $\begin{array}{l}\text { P\&D no Setor Elétrico Programa de P\&D regulado pela } \\
\text { Aneel }\end{array}$ \\
\hline Cieds & Report & Feb-13 & Relatório da Etapa 1 - Mapeamento \\
\hline Cieds & Report & Jun-13 & Relatório da Etapa 2 — Diagnóstico \\
\hline Cieds & Report & Dec-13 & $\begin{array}{l}\text { Relatório } 1 \text { da Etapa } 3 \text { - Formação da Rede e Câmaras } \\
\text { Técnicas }\end{array}$ \\
\hline Cieds & Action Plan & Mar-14 & Camaras tecnicas e Planos de Ação \\
\hline Cieds & Report & Jun-14 & Relatório 2 da Etapa 3 \\
\hline Cieds & Report & Sep-14 & $\begin{array}{l}\text { Relatório } 3 \text { da Etapa } 3 \text { - Implementação dos Planos de } \\
\text { Ação }\end{array}$ \\
\hline Cieds & Report & Dec-14 & $\begin{array}{l}\text { Relatório da Etapa } 3 \text { — Implementação dos Planos de } \\
\text { Ação }\end{array}$ \\
\hline Cieds & Action Plan & Jul-15 & Planos de Ação das Câmaras Técnicas \\
\hline
\end{tabular}


RAP | The influence of context in the implementation of a smart city project: the case of Cidade Inteligente Búzios

\begin{tabular}{|c|c|c|c|}
\hline Source & Type of document & Date & Title \\
\hline Cieds/Fundação BB & $\begin{array}{l}\text { Project Summary } \\
\text { (Certification) }\end{array}$ & Jun-15 & Rede Sustentável de Relacionamento \\
\hline Comunica Búzios & Internet Article & Jul-11 & $\begin{array}{l}\text { Ampla realiza vistoria técnica em Búzios para implantação } \\
\text { da Cidade Inteligente }\end{array}$ \\
\hline Comunica Búzios & Internet Article & Jul-11 & $\begin{array}{l}\text { Búzios será a primeira Cidade Inteligente da América } \\
\text { Latina }\end{array}$ \\
\hline Comunica Búzios & Internet Article & Dec-11 & $\begin{array}{l}\text { Prefeito Mirinho acompanha visita técnica da Ampla para } \\
\text { implantação do projeto Cidade Inteligente Búzios }\end{array}$ \\
\hline Comunica Búzios & Internet Article & Apr-12 & Inauguração posto Consciência EcoAmpla em Búzios \\
\hline Comunica Búzios & Internet Article & Nov-12 & $\begin{array}{l}\text { Inaugurado em Búzios o Centro de Monitoramento e } \\
\text { Pesquisa da primeira Cidade Inteligente da América Latina }\end{array}$ \\
\hline Exame & Magazine Article & Nov-12 & Ampla investe $\mathrm{R} \$ 40$ milhões em projeto em Búzios \\
\hline FGV & Report & Jan-13 & $\begin{array}{l}\text { Avaliação de imagem da Ampla e diagnóstico do Projeto } \\
\text { Cidade Inteligente em Búzios }\end{array}$ \\
\hline FGV & Report & Mar-13 & $\begin{array}{l}\text { Cidade Inteligente Búzios: Características demográfica } \\
\text { de Armação dos Búzios: síntese dos dados do censo } \\
\text { demográfico } 2010 \text { do IBGE }\end{array}$ \\
\hline FGV & Report & Mar-13 & $\begin{array}{l}\text { Cidade Inteligente Búzios: Características da economia } \\
\text { municipal de Armação dos Búzios }\end{array}$ \\
\hline FGV & Report & Mar-13 & $\begin{array}{l}\text { Cidade Inteligente Búzios: Índice de Satisfação com a } \\
\text { Qualidade Percebida (ISQP) Armação dos Búzios — } 2012\end{array}$ \\
\hline FGV & Report & Sep-16 & $\begin{array}{l}\text { Avaliação de imagem da Ampla e diagnóstico do Projeto } \\
\text { Cidade Inteligente em Búzios } 2012 \text { e } 2016\end{array}$ \\
\hline FGV & Report & Sep-16 & $\begin{array}{l}\text { Cidade Inteligente Búzios: Índice de Satisfação com a } \\
\text { Qualidade Percebida (ISQP) Armação dos Búzios — } 2012 \\
\text { e } 2016\end{array}$ \\
\hline G1 & Internet article & Apr-14 & $\begin{array}{l}\text { Escolas de Búzios, RJ, recebem painéis solares para gerar } \\
\text { energia }\end{array}$ \\
\hline G1 & Internet article & Nov-15 & $\begin{array}{l}\text { Equipe da UFRJ vence competição de barcos elétricos em } \\
\text { Búzios, no RJ }\end{array}$ \\
\hline Governo do Rio de Janeiro & Press release & Nov-12 & Ações inovadoras atraem mais investimentos para o Rio \\
\hline Governo do Rio de Janeiro & Press release & Sep-13 & Programa mobilidade elétrica é lançado em Búzios \\
\hline Governo do Rio de Janeiro & Press release & 11-Jul & $\begin{array}{l}\text { Programa "cidade inteligente Búzios" é lançado no Rio de } \\
\text { Janeiro }\end{array}$ \\
\hline KPMG & Report & Dec-12 & Infrastructure 100: World Cities Edition \\
\hline Landis+Gyr & Press release & Jul-12 & $\begin{array}{l}\text { Enel, Ampla and Landis+Gyr bring an advanced metering } \\
\text { solution to Brazil }\end{array}$ \\
\hline O Dia & Newspaper article & Dec-12 & Projeto faz de Búzios a primeira Cidade Inteligente \\
\hline
\end{tabular}


RAP | The influence of context in the implementation of a smart city project: the case of Cidade Inteligente Búzios

\begin{tabular}{|c|c|c|c|}
\hline Source & Type of document & Date & Title \\
\hline 0 Dia & Newspaper article & Aug-14 & $\begin{array}{l}\text { Búzios quer se transformar na cidade mais inteligente do } \\
\text { país }\end{array}$ \\
\hline 0 Globo & Newspaper article & Jul-12 & $\begin{array}{l}\text { Rua das Pedras, em Búzios, oferece rede gratuita de } \\
\text { internet }\end{array}$ \\
\hline 0 Globo & Newspaper article & Aug-12 & $\begin{array}{l}\text { Projeto Cidade Inteligente implantado em Búzios é } \\
\text { destaque em ranking internacional }\end{array}$ \\
\hline 0 Globo & Newspaper article & Nov-12 & $\begin{array}{l}\text { Búzios torna-se primeira cidade inteligente da América } \\
\text { Latina }\end{array}$ \\
\hline Portal Fator Brasil & Internet article & Feb-12 & $\begin{array}{l}\text { Balneário de Búzios recebe bicicletas ergométricas } \\
\text { inteligentes e chuveiros eficientes durante o carnaval }\end{array}$ \\
\hline Portal RC 24h & Internet article & Jan-12 & $\begin{array}{l}\text { Sebrae RJ analisa ações de Mirinho que apontam Búzios } \\
\text { como um dos municípios mais empreendedores do Estado }\end{array}$ \\
\hline Prefeitura de Búzios & Press release & Nov-13 & $\begin{array}{l}\text { Utilização das bicicletas faz parte do projeto Cidade } \\
\text { Inteligente }\end{array}$ \\
\hline Prefeitura de Búzios & Press release & Nov-14 & Búzios oferece wi-fi gratuito para a população \\
\hline Revista Cidade & Magazine article & Jan-12 & Consciência EcoAmpla para Búzios \\
\hline Sebrae & Report & Jul-05 & $\begin{array}{l}\text { Vencedores do VII Prêmio Sebrae Prefeito Empreendedor } \\
\text { 2011-2012 }\end{array}$ \\
\hline
\end{tabular}

Source: Elaborated by the authors. 